\title{
2184. Vibroacoustic diagnostics of a radial microturbine and a scroll expander operating in the organic Rankine cycle installation
}

\author{
Tomasz Z. Kaczmarczyk ${ }^{1}$, Grzegorz Żywica ${ }^{2}$, Eugeniusz Ihnatowicz ${ }^{3}$ \\ Department of Turbine Dynamics and Diagnostics, The Szewalski Institute of Fluid-Flow Machinery, PAS, \\ Gdańsk, Poland \\ ${ }^{1}$ Corresponding author

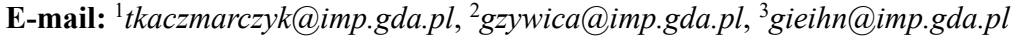

Received 14 March 2016; received in revised form 21 May 2016; accepted 31 May 2016

DOI http://dx.doi.org/10.21595/jve.2016.17167

\begin{abstract}
The article presents the results of vibroacoustic research on a prototypical 4-stage radial microturbine and a scroll expander operating in the organic Rankine cycle with the low-boiling fluid HFE7100. The high-speed microturbogenerator had the electrical capacity of $3 \mathrm{~kW}_{\mathrm{e}}$ at the nominal speed of $24000 \mathrm{rpm}$. The low-speed expander with a capacity of $1 \mathrm{~kW}_{\mathrm{e}}$ and a nominal speed of $3600 \mathrm{rpm}$ was made by Air Squared. The frequency characteristics and overall vibration level (vibration velocity Vrms) measurements were conducted for both the microturbine and the expander, depending on the rotational speed and on the power consumption of electrical energy receivers. The level of noise emitted by the microturbine and expander was also determined. The research was carried out for various electrical loads of the expansion devices generators running in the ORC system. The devices were tested in the following electric power ranges: from $550 \mathrm{~W}_{\mathrm{e}}$ to $1150 \mathrm{~W}_{\mathrm{e}}$ (scroll expander) and from $800 \mathrm{~W}_{\mathrm{e}}$ to $1800 \mathrm{~W}_{\mathrm{e}}$ (radial microturbine). Based on the obtained results, dynamic state assessment of the tested machines was performed and their noise and vibration levels were analysed.
\end{abstract}

Keywords: microturbine, scroll expander, vibration measurement, noise level, microturbine dynamics, ORC system.

\section{Introduction}

In recent years, the European Union has laid particular stress on application of renewable energy sources and waste heat utilization [1]. The term "micro-installation" has been defined in the Polish Law on renewable energy sources [2] as "renewable energy source with a total installed electric power of up to $40 \mathrm{~kW}$... with a total installed thermal power of up to $120 \mathrm{~kW}$ ". It should be noted that micro-installations are located on the premises of a homestead or in its immediate vicinity. This indicates that they must meet a number of specific national circumstances and requirements to ensure the physical safety and psychological comfort of the users. In line with this approach, it is essential to ensure low noise and vibration levels which adversely affect mood and health of people as well as quality of their work [3].

Noise is the second biggest environmental problem in the European Union, aside from air pollution. It is estimated that almost 67 million Europeans are exposed to excessive noise caused by motor vehicle traffic and almost 21 million people live in places in which the exceedances of permitted night-time noise levels were registered [4]. Widely available data for the year 2010 on actual occupational exposure to environmental noise (obtained from GUS - the Polish abbreviation for the Central Statistical Office) indicate that $41 \%$ of people in Poland were affected by noise exceeding the permissible limit, out of over 700000 workers exposed to hazardous levels of noise [5]. In Poland, 10 thousand people living in 41 towns were examined under the test entitled "National Hearing Test 2011". The results of this study have shown that one third of the persons from the examined population experienced hearing difficulties, and that this number is increasing among young people. In addition, it emerged that almost half of people under age 40 who took part in the study suffer from some kind of hearing loss [6-8].

There is therefore a need for research on noise emitted by industrial equipment and 
installations, since each equipment or installation has its own specific acoustic characteristics which may adversely affect the human body to different extent and in different ways [9]. The standards, PN-EN ISO 10052:2005(U) and PN-EN ISO 16032:2006, include the evaluation methods and permissible levels of noise in rooms, especially noise penetrating into rooms from technical equipment that is permanently installed inside and outside of a building (such as heating and cooling equipment, heat recovery ventilators, pumps, transformers and other ancillary equipment) $[10,11]$.

The eight-hour audible noise exposure level should not be higher than $85 \mathrm{~dB}(\mathrm{~A})$ in all working areas. The maximum sound level is $115 \mathrm{~dB}(\mathrm{~A})$ and the peak sound level is $135 \mathrm{~dB}(\mathrm{C})$ [12, 13]. According to the relevant standard ISO 1999, if the exposure to the sound level does not exceed $80 \mathrm{~dB}(\mathrm{~A})$ over a period of 40 years the risk of permanent hearing impairment is $0 \%$ [14]. Moreover, noise emission also entails environmental impact and this fact has been the driving force to revise the legislative framework, resulting in laying down the penalties for exceedances of permissible noise levels [15]. As a consequence, the manufacturers of devices, in accordance with [16], must therefore submit a Declaration of Conformity to the competent authorities (i.e. the European Commission and the appropriate institution subordinate to the Minister of Economy). For instance, in line with the ordinance of the Minister of Economy [17], the allowable sound power level for compressor units is $97 \mathrm{~dB} / 1 \mathrm{pW}$ for an installed capacity $P \leq 15 \mathrm{~kW}$ and $95+2 \lg P$ for a capacity above $15 \mathrm{~kW}[18]$.

Reducing noise and vibration is emphasized in the Ordinances of the Minister of Economy and Directives of the European Parliament and of the Council relating to machinery [19-23] by the following statement: "devices must be designed and manufactured in such a way as to reduce to the lowest possible level the risks arising from vibration (noise) generated by the devices, taking account of technical progress and of the means available for limiting vibrations (noise), particularly at source, unless the vibrations are part of the specified performance" [24]. Noise reduction at source means that in the case of newly manufactured devices, already at the designing stage, the noise emission requirements concerning these devices should be taken into account, and in the case of devices and machinery already in service, steps should be taken in order to create the technical conditions guaranteeing the fulfilment of the applicable guidelines concerning noise emissions according to the approved standards of the European Union [25].

The measurements found in literature, concerning cases where vibration or noise emission limit values are exceeded, were mainly carried out on large facilities across a broad spectrum of industries [57, 58]. Jaskólski and Budzik [26] made infrasound measurements of the SO-3 jet engine that have demonstrated that the time average of the daily noise exposure levels for a nominal week of five eight-hour working days were exceeded at the rotational speeds of $13000 \mathrm{rpm}$ and $15000 \mathrm{rpm}$ for the octave band $31.5 \mathrm{~Hz}$. For speeds in the range 7000 to $12000 \mathrm{rpm}$ and octave bands 2 to $16 \mathrm{~Hz}$, the sound level was within the 82-105 dB range, thus below the value permitted by the relevant standard. The sound level of the TW3-117 turbine engine was within the range of 62-86 $\mathrm{dB}$ and did not exceed the permissible values stated in the Polish Standard PN-86/N-01338 over the full range of octave bands (i.e. from 2 to $31.5 \mathrm{~Hz}$ ).

Klimanowski [27] has analysed the PN and ISO applicable regulations relating to vibroacoustic diagnostics of fluid-flow machinery (i.e. steam turbines, rotodynamic pumps, fans, generators). The standards review has shown that the ISO 10816-3:2009 is recommended for machines with nominal power above $15 \mathrm{~kW}$ and nominal speeds between $120 \mathrm{rpm}$ and $15000 \mathrm{rpm}$ when measured in situ. Despite the recommendations that the evaluation of dynamical state of machinery should be carried out in accordance with the manufaturers' guidelines, PN-ISO 10816-1:1998 became the most common standard used for this purpose [28]. The ISO standard 10816 sets forth general requirements for the vibration levels and dynamic stiffness coefficients for turbines, which are 1.5 and 5 for low and high pressure turbines, respectively. It is stressed that these values should only be implemented on a limited basis [29]. Diagnostics and quality assessment of gears and compressors should be performed according to the ISO 10816-3 (2009) and supplemented by the standard VDI 3836 (2012) [30]. 
Kumaraswamy et al. [31] have assessed the suitability of standards used for vibration analysis of precision machine tools. They claim that the ISO 2372 (RMS velocity in the frequency range from $10 \mathrm{~Hz}$ to $1 \mathrm{kHz}$ ) and the Canadian specifications (RMS velocity in the frequency range from $10 \mathrm{~Hz}$ to $10 \mathrm{kHz}$ ) are only applicable to general purpose machinery (e.g. pumps, motors, generators, etc.) and they should not be used for vibration level analysis relating to precision machine tools.

Kromulski et al. [32] conducted the research on mechanical vibrations produced by a mobile grain pneumatic conveyor. The dynamic state assessment of this machine was carried out with reference to PN-ISO 10816-1:1998, according to which the conveyor needs to be categorised as a class II medium-sized machine with a capacity from 15 to $75 \mathrm{~kW}$ not requiring special foundations. The maximum RMS of the vibration velocity, determined at bearings location in the conveyors blower, was approx. $26.6 \mathrm{~mm} / \mathrm{s}$ and exceeded the permissible value stated in the above standard. Nevertheless, in the light of the ISO 2372, the conveyor may be classified as a class V machine with unbalanced forces of inertia or as a class VI machine with an unbalance changing during its operation. According to ISO 2372 the class V machines can operate reliably at speeds of up to $30 \mathrm{~mm} / \mathrm{s}$.

Regular measurements of noise are useful when carrying out research on turbine vibration, in particular in the case of vibrations of blades caused by transonic flows of steam in a diffuser. This kind of phenomena are often observed during supersonic flow at turbine blade tips, under strong turbulence conditions, in particular at turbine gland seals [28, 33]. Excessive levels of vibration or noise are often the cause of premature wear of machine parts, which results in disturbances influencing upon the production process such as stoppages due to a failure [28]. Moreover, the gradual degradation of structural components of turboset and steam turbines flow system goes hand in hand with the reduction of turbine internal efficiency. Hence the need for monitoring of the wear of the mechanical components, which provides the opportunity to plan ahead and combine the refurbishment and maintenance, and thus avoid a machine damage [34].

For instance, Toczek [33] performed vibroacoustic analysis of a modernized 13CK 70 turbine (with the capacity of $70 \mathrm{MW}_{\mathrm{e}}$ ) and identified excessive noise and vibration levels, which could cause a damage to this turbine. On the basis of research carried out, it has been found that the malfunctioning bearing system resulted in an increased level of vibration. The four-wedge bush bearing was used in order to reduce vibrations induced by aerodynamic forces acting on elements located near the turbine seals. This configuration shifted the stability threshold and enabled safe operation of the rotor shaft over a broader range of displacements.

Wachel [35] investigated vibration levels in a three-stage steam turbine (with the capacity of 13000 h.p.) and an eight-stage syngas compressor in rotational speed range from $2000 \mathrm{rpm}$ to $12000 \mathrm{rpm}$. It turned out that the first and second critical speeds of the compressor shaft occurred at $4320 \mathrm{rpm}$ and $6200 \mathrm{rpm}$, respectively. As for the turbine, the vibration amplitude was $1.5 \mathrm{~mm}$ at $11580 \mathrm{rpm}$ and around $16 \mathrm{~mm}$ at $4000 \mathrm{rpm}$.

Induction motors are nowadays very often applied in these drives which are operating within a wide range of rotational speeds, resulting in fluctuating levels of vibration and noise. Motor power shift mostly takes place through PWM converters, which may increase natural vibrations of the motor and cause resonance. Therefore, such motors are often at the core of scientific or industrial research [36].

Szymaniec [37] carried out research on three high-powered engines. The $630 \mathrm{~kW}$ engine with the rated speed of $1480 \mathrm{rpm}$, connected to an inverter, was characterized by a high vibration level at two rotational speeds $(1130 \mathrm{rpm}$ and $1360 \mathrm{rpm})$, which turned out to be its resonant speeds. The rundown test conducted for the engine with the capacity of $1 \mathrm{MW}$ and the rated speed of $2986 \mathrm{rpm}$ have shown very high RMS values of vibration velocity, i.e. $8-10 \mathrm{~mm} / \mathrm{s}$. For the third engine, with the capacity of $6.3 \mathrm{MW}$ and the nominal speed of $1490 \mathrm{rpm}$, operating in a system equipped with the electric pump, frequencies of the vibrations induced by elecromagnetic forces were determined. These frequencies were close to resonant frequencies, which had the effect of increasing the vibrations. Magnetic field and surge voltages had a considerable influence on elevated vibration 
levels [37].

Żywica et al. [38] analysed the dynamical state of the hydro set equipped with a $600 \mathrm{~kW}$ Kaplan turbine, which is installed in a hydroelectric power plant. The research was conducted in accordance with ISO 10816-1:1995 and ISO 10816-5 standards, on the basis of which the hydro set was classified as a class IV machine, i.e. vertical machines. The tests were carried out for several power loads (such as $105 \mathrm{~kW}, 200 \mathrm{~kW}, 307 \mathrm{~kW}, 403 \mathrm{~kW}$ and $480 \mathrm{~kW}$ ) and, on their basis, it has been found that the maximum permitted level of RMS vibration velocity was exceeded. The maximum permitted values for class IV machines are as follows: $A_{P-P}=30 \mu \mathrm{m}$ and $V_{R M S}=1.6 \mathrm{~mm} / \mathrm{s}$ for bearings mounted on a foundation frame, $A_{P-P}=65 \mu \mathrm{m}$ and $V_{R M S}=2.5 \mathrm{~mm} / \mathrm{s}$ for bearings mounted above a foundation (where $A_{P-P}$ stands for the peak to peak vibration amplitude and $V_{R M S}$ represents RMS vibration velocity).

Jarzyna [39] measured the vibrations of a two-stage mixed flow pump and identified the harmonic component with a frequency around $74 \mathrm{~Hz}$, which may have occurred due to liquid streams flowing from the rotor vanes and traveling to guide vanes. His finding was strengthened by the point that there is a change in the direction of fluid flow from axial to radial flow in the outlet part of the pump, and this affects the level of vibrations transmitted on the machine body.

Since scroll compressors vibration signals are non-stationary and non-linear, this makes it very difficult to identify the actual signal spectrum. Liu and $\mathrm{Wu}$ [40] proposed the analysis based on wavelet entropy method in order to measure vibration of a scroll compressor. Two forms of the wavelet entropy, namely the wavelet space feature spectrum entropy (WSFSE) and the wavelet energy spectrum entropy (WESE), enable to study instantaneous characteristics of vibration signals in both the time and frequency domains simultaneously, providing the full information on signal spectra.

Rockwood [41] applied the SEA method during performing a dynamical diagnostic of a 10 -tonne scroll compressor. In this method, resonant values are not counted in the average value, therefore the SEA method is especially recommended for trend analysis, which can be particularly useful early in the design process for prediction of response peaks.

The selection of an appropriate standard which is used in vibration analysis of machines and non-stationary devices, particularly in a system comprising machines with deformable bodies that are supported by flexible steel structures, is a complex task [42].

A new approach, based on modern methods, is therefore needed to deal with analysing vibration of machinery. For instance, Zargar [43] presented a broad overview of measurement methods. The Bently Nevada monitoring system, which allows the use of the time wave form (TWF) and fast Fourier transform (FFT) analyses, was applied for monitoring of vibration level of a steam turbine's multistage compressor (MPC-C-8001).

Grządziela [44] proposes to carry out technical condition assessment of rotating machines on the basis of measurements conducted in transient states without having to apply synchronising signals. Such approach can be successfully used for stationary turbine sets and marine diesel engines. The identification of unbalance is implemented through the autotracking procedure, which is particularly useful where it is not possible to obtain a direct synchronising signal.

Pursuant to the requirement to reduce noise and vibration level at source, Kiciński et al. [45] performed, at an early stage in the design process, the dynamic state assessment of the rotor used in a $3 \mathrm{~kW}_{\mathrm{e}}$ five-stage axial vapour microturbine (with the nominal speed of $8073 \mathrm{rpm}$ ) which was designed to operate in an ORC installation. Thermal power of the cogeneration system equipped with the microturbine was approximately $25 \mathrm{~kW}_{\mathrm{t}}$. Based on computational analysis, dynamical characteristics of the rotor supported either by slide or rolling bearings were determined. The research was carried out by means of the computer programs of the MESWIR series that were created at the IFFM PAS in Gdansk and also using ABAQUS and MADYN 2000 commercial software. The paper [46] describes the dynamical analysis of the single-stage axial-flow microturbine's rotor supported by slide bearings, which had the rotational speed of around $83000 \mathrm{rpm}$. Due to considerable thermal loads (at the level of $160^{\circ} \mathrm{C}$ ) affecting the microturbine, 
the thermal analysis was conducted with the aim of assessing thermal stresses and deformations of the rotor.

Żywica et al. [47, 48] made the dynamic and kinetostatic analysis of a four-stage vapour microturbine with gas bearings. The microturbine had the rated power of $3 \mathrm{~kW}_{\mathrm{e}}$, which was reached at the speed of approx. $24000 \mathrm{rpm}$. ANSYS software and the computer programs included in the MESWIR series were used for the analysis. The maximum stress value was about $34.7 \mathrm{MPa}$ at the rotational speed of $23800 \mathrm{rpm}$ and it was around three times lower than the permitted value. The maximum vibration amplitude was approximately $0.8 \mu \mathrm{m}$. Thermal analysis of the microturbine was performed by means of ABAQUS software, which demonstrated the need for use of the machine body cooling system.

It follows from the above literature review that practically no data is available to date as regards research on noise and vibration levels for small power machinery, i.e. with capacities below $40 \mathrm{~kW}_{\mathrm{e}}$. In accordance with the requirements included in the Directive 2006/42/EC, the Ordinance of the Minister of Economy [49] and the Ordinance of the Minister of Labour and Social Policy [50], vibroacoustic tests of the two types of expansion devices were carried out, during their operation in the cogeneration ORC installation with the low-boiling working medium HFE7100. The following expansion devices were examined: $3 \mathrm{~kW}_{\mathrm{e}}$ prototypical four-stage radial microturbine [51] and $1 \mathrm{~kW}_{\mathrm{e}}$ commercial scroll expander [52, 53].

\section{Test bench}

The ORC system, installed in the Micro CHP Power Plant Laboratory, is composed of three basic cycles: heating cycle, cooling cycle and working fluid cycle. The heating cycle consists of a group of oil pumps and two independent heat sources: a multifuel boiler and a set of two electric thermal oil heaters that can work independently or in series/in parallel. The prototypical electric flow oil heater consists of two modules. Both modules can work independently or in series and are designed to heat non-conductive fluids (thermal oil) to the temperature of about $250{ }^{\circ} \mathrm{C}$ with low electrical power density and the power of $2 \times 24 \mathrm{~kW}$. The prototypical boiler enables combustion of gas fuel (GZ-50 or syngas) or solid fuel in the form of biomass (pellets). The maximum power of the boiler is about $30 \mathrm{~kW}_{\mathrm{t}}$. The prototypical plate heat exchanger with a heat transfer surface area of $4.1 \mathrm{~m}^{2}$ acted as an evaporator in the heating circuit. In the case of the heat regenerator the shell-coil heat exchanger with a heat transfer surface area of $2.3 \mathrm{~m}^{2}$ was used. The prototypical plate condenser with a heat transfer surface area of $3.2 \mathrm{~m}^{2}$ was applied in the cooling circuit. The ORC installation can work using an expansion valve, a microturbine or a group of expanders.

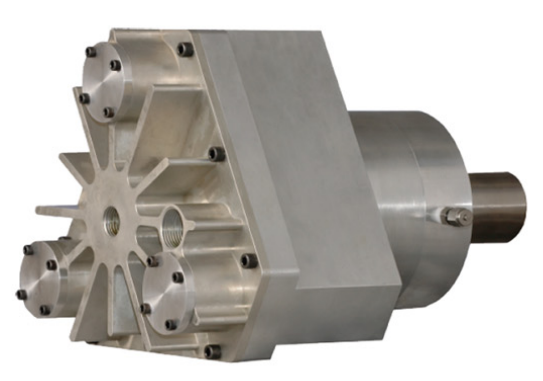

\begin{tabular}{|l|l|}
\hline model & E15H22N4.25 \\
\hline nominal output & $1 \mathrm{~kW}$ \\
\hline max. inlet pressure & $13.8 \mathrm{bar}$ \\
\hline max. speed & $3600 \mathrm{rpm}$ \\
\hline max. inlet temperature & $175^{\circ} \mathrm{C}$ \\
\hline displacement & $12 \mathrm{~cm}^{3} / \mathrm{rev}$. \\
\hline volume ratio & 3.5 \\
\hline media & refrigerant, other \\
\hline nominal sound level & $55 \mathrm{~dB}(\mathrm{~A})$ \\
\hline net weight & $9.07 \mathrm{~kg}$ \\
\hline
\end{tabular}

Fig. 1. Technical parameters of the scroll expander [53]

\subsection{Test bench for scroll expanders}

The test bench allows for testing of two expanders working in different configurations: in parallel, in series or in a single arrangement expander system. It enables carrying out expanders 
tests using HFE7100 as the working fluid when the pressure of the low-boiling working fluid vapour is about 14 bar. The Air Squared scroll expanders [54] are equipped with electromagnetic clutches and electric generators whose nominal rotational speed is $3600 \mathrm{rpm}$. The technical parameters of the scroll expander are presented in Fig. 1.

Photo of the ORC system and measurements scheme of the test bench with scroll expanders are presented in Fig. 2 and Fig. 3.

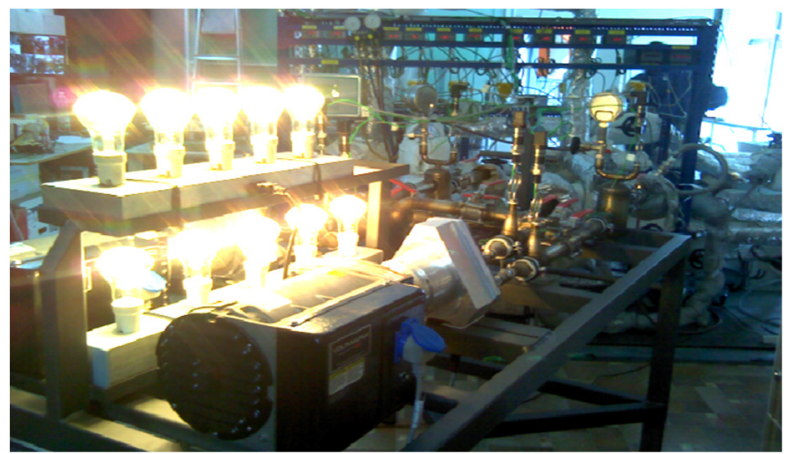

Fig. 2. Photo of the ORC system with scroll expanders

The test bench with expanders allows for work in different configurations:

- configuration 1: work without expanders (by-pass);

- configuration 2: work of expander 1 (expander 2 turned off);

- configuration 3: work of expander 2 (expander 1 turned off);

- configuration 4: work of expander 1 and expander 2 (work in series);

- configuration 5: work of expander 1 and expander 2 (work in parallel).

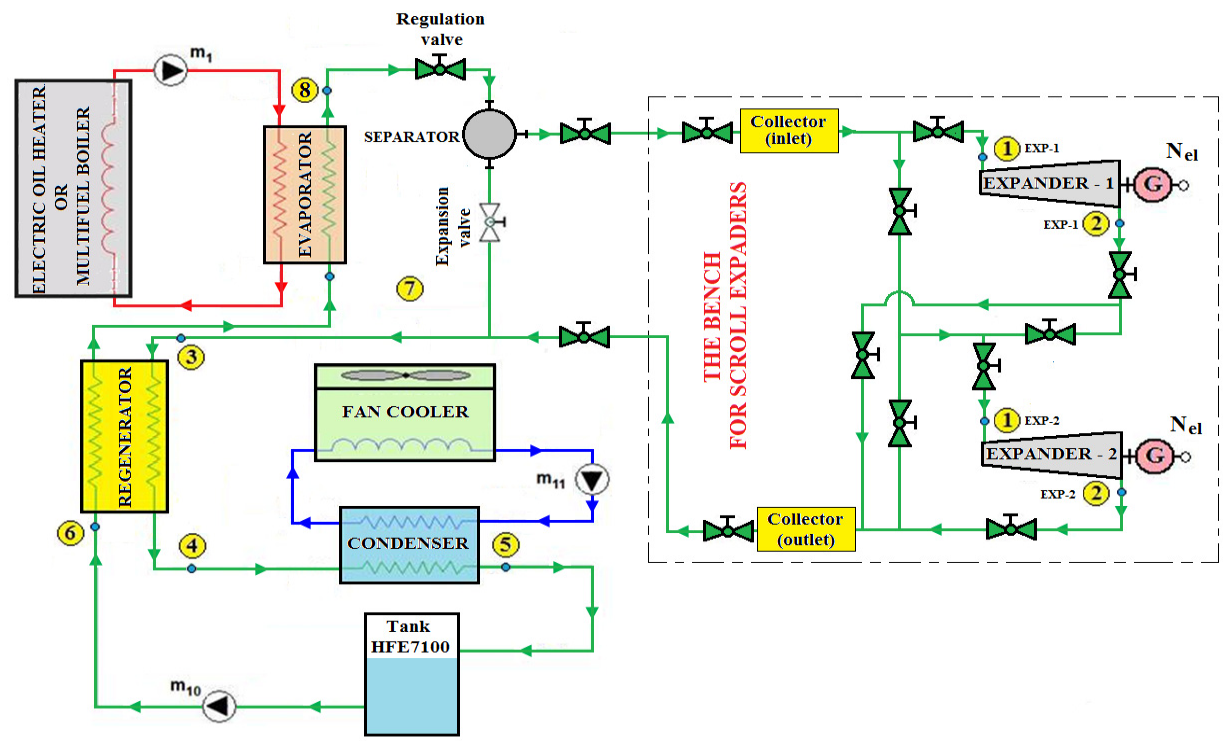

Fig. 3. Measurements scheme of the ORC system with scroll expanders

The test bench consists of an electric load system and a data acquisition system to process the following measurement data: thermodynamic parameters (temperature and pressure of the working fluid) and electrical parameters (rotational frequency of the electric generator, current, voltage and power consumed by the electrical load). The data acquisition and measuring system comprises the National Instruments (NI) system and the application created in the LabView 
environment. The test bench is equipped with a module which enables the measurement of the following parameters: rotational frequency of the expander shaft $(0-100 \mathrm{~Hz})$, load current $(0-25 \mathrm{~A})$ and voltage $(0-250 \mathrm{~V})$. Furthermore, the installation has two collectors (inlet and outlet) and a group of control valves allowing for testing expanders in different configurations. A set of five light bulbs of $1 \mathrm{~kW}_{\mathrm{e}}$ in total was used as an electrical load for each scroll expander.

The analysis of noise and vibration levels of the ORC system was carried out only for the scroll expander no. 1 (i.e. configuration 2).

\subsection{Test bench for radial microturbine}

The ORC system cooperates with the high-speed four-stage radial microturbine whose parameters are as follows: nominal power $2.7 \mathrm{~kW}_{\mathrm{e}}$, nominal rotational speed $24000 \mathrm{rpm}$ and isentropic efficiency about $70 \%$. The technical data of the microturbine are shown in Fig. 4.

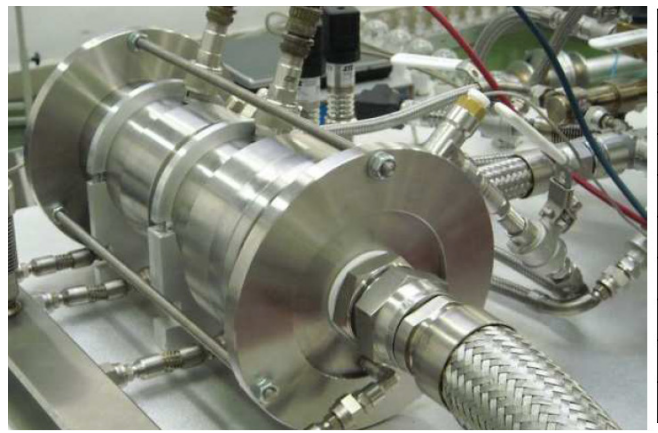

\begin{tabular}{|l|l|}
\hline type & radial \\
\hline number of stages & 4 \\
\hline nominal output & $2-3 \mathrm{~kW}$ \\
\hline max. inlet pressure & $14 \mathrm{bar}$ \\
\hline max. speed & $25000 \mathrm{rpm}$ \\
\hline max. inlet temperature & $180^{\circ} \mathrm{C}$ \\
\hline max. flow rate & $0.17 \mathrm{~kg} / \mathrm{s}$ \\
\hline medium & $\mathrm{HFE7100}$ \\
\hline nominal sound level & $43 \mathrm{~dB}(\mathrm{~A})$ \\
\hline net weight & $10 \mathrm{~kg}$ \\
\hline
\end{tabular}

Fig. 4. Technical data of the radial microturbine

The microturbine shaft is integrated with an electric energy generator and encased in a sealed housing. Given the oil-free construction and the high rotational speed, aerostatic gas bearings powered by a low-boiling medium vapour were used. The microturbine is equipped with a control and measurement system which assures good functioning of the device as well as reception and conditioning of electric energy. The ORC test bench with the radial microturbine and measurements scheme are presented in Fig. 5 and Fig. 6.

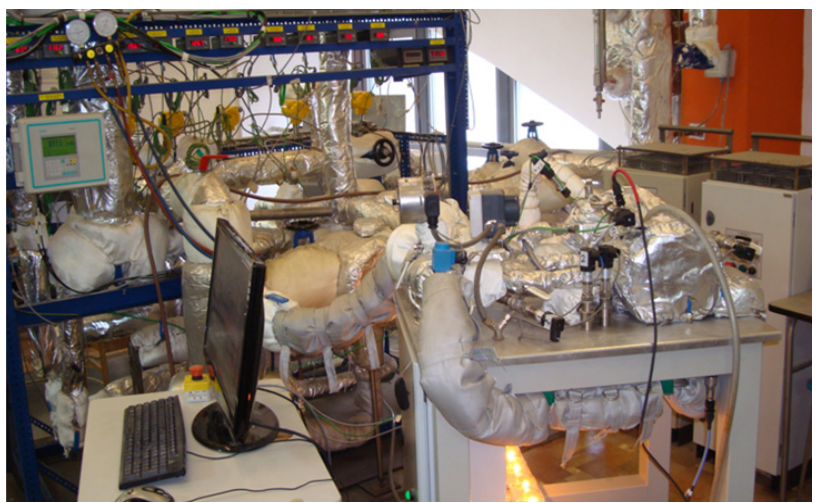

Fig. 5. Photo of the ORC system with a radial microturbine

\subsection{Measurement procedure and apparatus}

The vibration level measurements of the tested machines (radial microturbine and scroll expander) were carried out using a portable vibration analyzer CSI 2140, manufactured by Emerson [55]. All vibration level measurements were conducted during steady state operation of 
the expansion devices. The vibration level was measured on the microturbine body. In the case of the scroll expander, the measurement was performed on the frame, since the machine body is made of aluminium alloy. The vibrations of the expander's generator were measured on its body. The noise level of the ORC installation with the radial microturbine and scroll expander was measured by means of a portable sound analyzer Nor140, manufactured by Norsonic [56]. Similarly, as in the case of vibration measurements, the noise level measurements of the expansion devices were carried out during their steady state operation. The diagram showing the location of the ORC installation, expansion devices and noise measurement points in the laboratory is presented in Fig. 7.

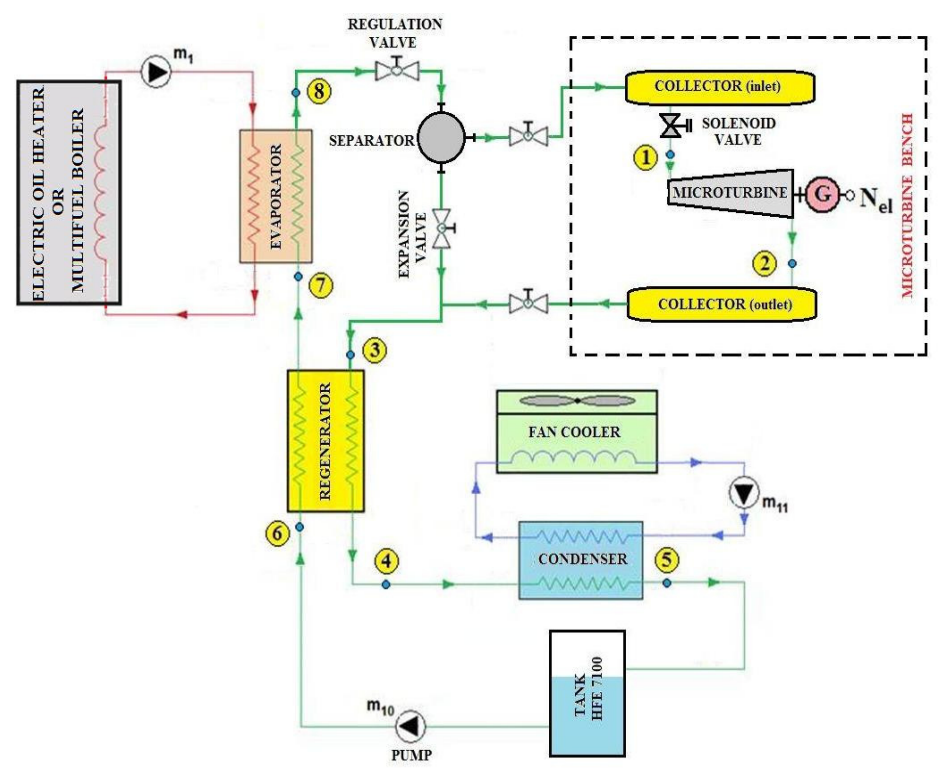

Fig. 6. Measurements scheme of the ORC system with a radial microturbine

The noise emitted by expansion devices was measured in three locations P1, P2 and P3 (see Fig. 7) for a period of not less than 10 seconds, half a meter away from machine bodies $(d=0.5 \mathrm{~m})$, at a height of about $1.5 \mathrm{~m}$ above the foundation level.

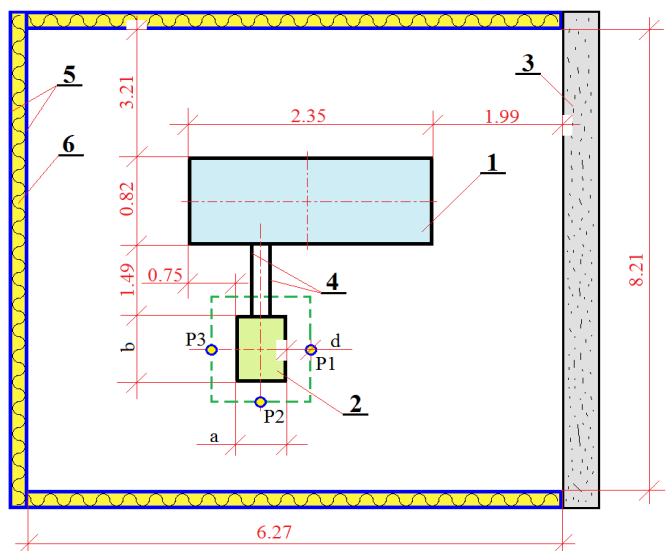

Fig. 7. Diagram showing the location of noise measurement points, ORC installation and expansion devices in the laboratory room: 1 - ORC installation, 2 - tested expansion devices,

3 - reinforced concrete wall, 4 - flexible connections to expansion devices,

5 - cardboard-gypsum slabs, 6 - acoustic insulation - mineral wool 


\section{Measurement results}

\subsection{Noise level of expansion machines}

Prior to proceeding to the measurements of sound emission of expansion machines, the first thing that had to be done was determining the background noise in the laboratory room in which the ORC installation is situated as well as microturbine and expander test rigs. Subsequently, the background noise was analyzed when individual devices operating in the ORC cycle were switched on. The average values of the background noise level measured in the ORC laboratory are shown in Fig. 8.

\begin{tabular}{|c|l|c|c|}
\hline \multirow{2}{*}{ No. } & \multicolumn{1}{|c|}{$\begin{array}{c}\text { Conditions for measuring the sound level } \\
\text { (on the bench ORC) }\end{array}$} & \multicolumn{2}{c|}{ Sound level } \\
\cline { 3 - 4 } $\mathbf{1}$ & $\begin{array}{l}\text { all devices cooperating with the installation of the } \\
\text { ORC switched off (measuring only sounds coming } \\
\text { from the hall) }\end{array}$ & 41.4 & 49.6 \\
\hline $\mathbf{2}$ & $\begin{array}{l}\text { the same conditions as in Mode no. 1 d data } \\
\text { acquisition and measurement system was switched on }\end{array}$ & 45.4 & 51.4 \\
\hline $\mathbf{3}$ & $\begin{array}{l}\text { the same conditions as in Mode no. 2+ oil pump } \\
\text { (integrated into the heating cycle) was switched on }\end{array}$ & 46.1 & 53.5 \\
\hline $\mathbf{4}$ & $\begin{array}{l}\text { the same conditions as in Mode no. 3+ electric flow } \\
\text { oil heater was running at no load }\end{array}$ & 60.2 & 65.1 \\
\hline $\mathbf{5}$ & $\begin{array}{l}\text { the same conditions as in Mode no. 4+ electric flow } \\
\text { oil heater was running }\end{array}$ & 60.9 & 65.5 \\
\hline $\mathbf{6}$ & $\begin{array}{l}\text { the same conditions as in Mode no. 5 + other } \\
\text { components in the ORC installation were switched on } \\
\text { (operation without expansion devices) }\end{array}$ & 62.6 & 66.1 \\
\hline
\end{tabular}

Fig. 8. Average levels of background noise in the laboratory and the devices working in the ORC system

The average background noise level $L_{\text {Aeq }}$ ranged from $41.4 \mathrm{~dB}$ to $62.6 \mathrm{~dB}$, and the average background noise level $L_{C e q}$ was within the range from $49.6 \mathrm{~dB}$ to $66.1 \mathrm{~dB}$. The highest increase in the value of $\Delta L_{A e q}$ occurred when the electric instantaneous oil heater was turned on and amounted to approx. $15 \mathrm{~dB}$, and increase in the value of $\Delta L_{C e q}$ was equal to $12 \mathrm{~dB}$.

In order to determine sound and vibration levels of the expanders throughout the rotational speed operating range, the measurements were carried out at varying electrical loads of the generators. The set of bulbs, that was switched on or off during operation of expansion devices, was applied to simulate electric load changes.

The influence of the rotational speed of the scroll expander (with generator) and the radial microturbine on the electrical power (load) is shown in Fig. 9(a) and Fig. 9(b), respectively.

The electrical power increases with rotational speed - regardless of the expansion device used (microturbine or scroll expander).

The influence of the rotational speed and the electric power (load) of the scroll expander on the noise level is shown in Fig. 10(a) and Fig. 10(b), respectively. These curves allow to determine the precise level of noise emitted by the expander for a given value of rotational speed or electrical power.

With the increase of electrical power and rotational speed of the scroll expander the average noise level decreases, according to correction characteristic A (dashed line), from $79.8 \mathrm{~dB}$ to $79.4 \mathrm{~dB}$. The arithmetic mean value of the measurements was $L_{\text {Aeq }}^{E x}=79.6 \mathrm{~dB}$. The increase in the sound level with the increase of electric power and rotational speed of the scroll expander from $83.0 \mathrm{~dB}$ to $83.4 \mathrm{~dB}$ occurred with the noise characteristics $\mathrm{C}$ (dashed line) and the arithmetic mean value of the measurements was $L_{C e q}^{E x}=83.2 \mathrm{~dB}$.

The effect of the rotational speed and the electric power (load) of the radial microturbine on 
the noise level is shown in Fig. 11(a) and Fig. 11(b), respectively. These curves make it possible to determine the noise level emitted by this device for a given value of rotational speed or electrical power.
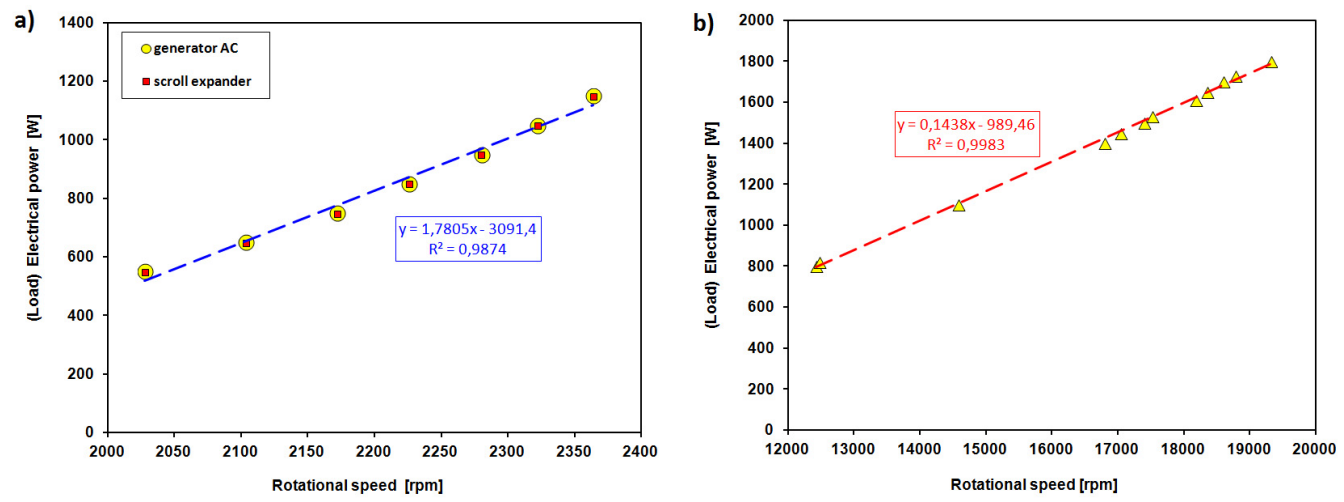

Fig. 9. Electrical power vs. rotational speed for: a) scroll expander with generator, b) radial microturbine
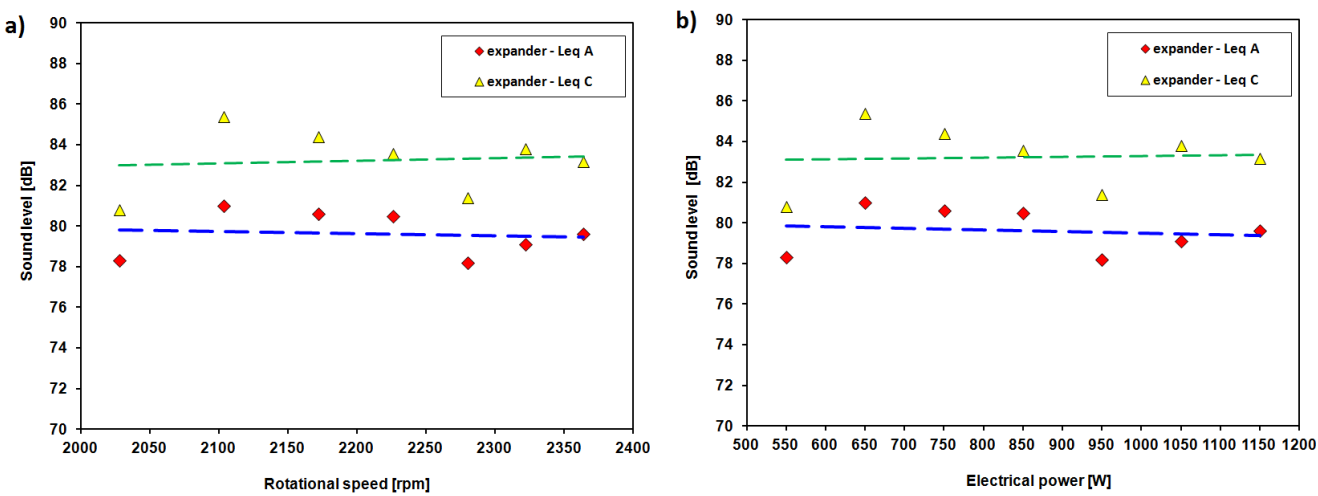

Fig. 10. Noise level of the scroll expander cooperating with an ORC installation vs a) expander's rotational speed, b) electrical power (generator load)
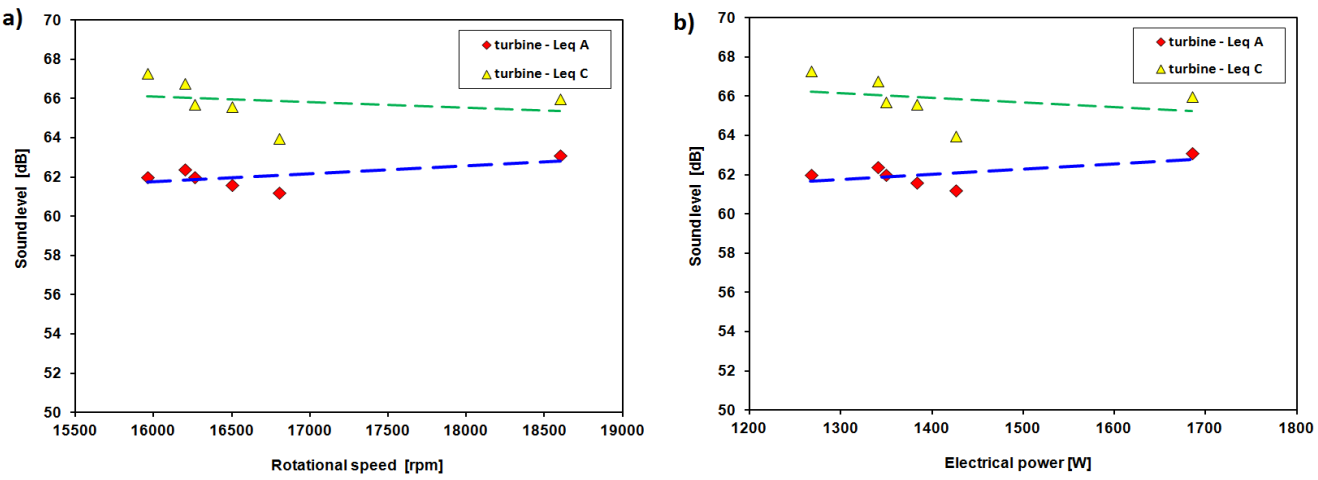

Fig. 11. Noise level of the radial microturbine cooperating with an ORC installation vs a) microturbine's rotational speed, b) electrical power (load)

With the increase of electrical power and rotational speed of the microturbine average noise increases (from $61.8 \mathrm{~dB}$ to $62.8 \mathrm{~dB}$ ) according to correction characteristic A (dashed line) and the arithmetic mean value of the measurements was $L_{\text {Aeq }}^{\text {Turb }}=62.1 \mathrm{~dB}$. The level of sound emitted by the microturbine, according to the correction characteristic $\mathrm{C}$ (dashed line), decreased from 
$66.2 \mathrm{~dB}$ to $65.2 \mathrm{~dB}$ with the increase of electric power and rotational speed, and the arithmetic average of the measurements was $L_{C e q}^{\text {Turb }}=65.9 \mathrm{~dB}$. It should be noted that the arithmetic means of the measurements of microturbine noise are lower than the average background levels (Fig. 8) by approx. $0.5 \mathrm{~dB}$ for noise correction characteristic $\mathrm{A}$ and by approx. $0.2 \mathrm{~dB}$ for the correction characteristic $\mathrm{C}$. This may be caused by an error in the noise measurements since the maximum permissible error for the sound analyzer is $\pm 0.2 \mathrm{~dB}$. Moreover, the operating parameters of the pumps and electronic instantaneous oil heater can change slightly during microturbine operation in the ORC installation, which may affect the noise level. Further analysis was carried out using the following average noise emission values: $L_{\text {Aeq }}^{\text {Turb }}=62.1 \mathrm{~dB}$ for the radial microturbine, $L_{\text {Aeq }}^{E x}=79.6 \mathrm{~dB}$ for the scroll expander and $L_{A e q}=62.6 \mathrm{~dB}$ as background noise level.

The emission sound pressure level $L_{p A}$ at the test bench for expansion devices was calculated in accordance with the following equation:

$L_{p A}=L_{A e q}^{E M}-K_{1 A}-K_{2 A} \mathrm{~dB}$,

where $L_{\text {Aeq }}^{E M}$ is a measured value of the average sound pressure level of the expansion devices (radial microturbine $-L_{A e q}^{\text {Turb }}$ or scroll expander $-L_{A e q}^{E x}$ ); $K_{1 A}$ and $K_{2 A}$ are the correction factors relating to background noise and acoustic absorption of the laboratory, respectively. The correction factor relating to background noise can be calculated using the following formula:

$K_{1 A}=-10 \log \left(1-10^{-0.1 \cdot \Delta L}\right) \mathrm{dB}$

where $\Delta L$ is the difference between the sound pressure level of the running expansion device $\left(L_{\text {Aeq }}^{E M}\right)$ and the background sound pressure level $\left(L_{A e q}\right)$, which can be determined using the following formula:

$\Delta L=L_{\text {Aeq }}^{E M}-L_{\text {Aeq }} \mathrm{dB}$

If $\Delta L \geq 10 \mathrm{~dB}$ and $\Delta L<3 \mathrm{~dB}$ then $K_{1 A}=0$. However, if $3 \leq \Delta L<10 \mathrm{~dB}$ then the value of the correction factor $K_{1 A}$ have to be calculated by Eq. (2).

The value of the correction factor relating to the acoustic absorption of the laboratory room $K_{2 A}$, was calculated by applying the following formula:

$K_{2 A}=10 \log \left(1+4 \frac{S}{A}\right) \mathrm{dB}$

where: $A=\alpha S_{v}$ in $\mathrm{m}^{2}$-absorption area of the laboratory room, $\alpha$ - average coefficient of sound absorption in the laboratory room, $S_{v}$ in $\mathrm{m}^{2}$ - total surface area of the laboratory room, $S=2 \pi d^{2}$ in $\mathrm{m}^{2}$ - total surface of the measurement area, $d$ in $\mathrm{m}$ - the smallest distance from the sound source (tested machine).

The value of the average sound absorption coefficient of the laboratory room may be determined from PN-EN ISO 3746 standard or calculated using the following formula:

$\alpha=\frac{\alpha_{1} F_{1}+\alpha_{2} F_{2}+\cdots+\alpha_{n} F_{n}}{F_{1}+F_{2}+\cdots+F_{n}}$

where: $\alpha_{1}, \alpha_{2}, \ldots, \alpha_{n}$ - sound absorption coefficients of particular surfaces $\left(F_{1}, F_{2}, \ldots, F_{n}\right)$ in the laboratory.

The sound power level $\left(L_{p A}\right)$ of noise sources (expansion devices), taking into account sound-reflecting surfaces, was calculated by applying the following equation: 


$$
L_{w}=L_{p A}+10 \log \frac{S}{S_{o}} \mathrm{~dB}
$$

where: $S_{o}$ - value for the reference surface equal $1 \mathrm{~m}^{2}$.

The following parameter values were applied for the analysis carried out: average coefficient of sound absorption in the laboratory room $\alpha=0.15$, total surface area of the laboratory room $S_{v}=143.57 \mathrm{~m}^{2}$. In the case of the radial microturbine the value of $\Delta L$ was less than $3 \mathrm{~dB}$, which means that more precise method of noise level measurement should be applied (described in ISO 3740 and ISO 9614 standards). The noise pressure level of the ORC installation coupled with the microturbine does not exceed $62.6 \mathrm{~dB}(\mathrm{~A})$, i.e. the background noise level. However, the noise level of the scroll expander attained a value of about $81.6 \mathrm{~dB}(\mathrm{~A})$, which was over $26 \mathrm{~dB}(\mathrm{~A})$ higher than that stated by the manufacturer.

\subsection{Mechanical vibration of expansion machines}

The effect of the rotational speed and the electrical power (load) on the RMS vibration velocity of the radial microturbine is shown in Fig. 12(a) and Fig. 12(b), respectively.
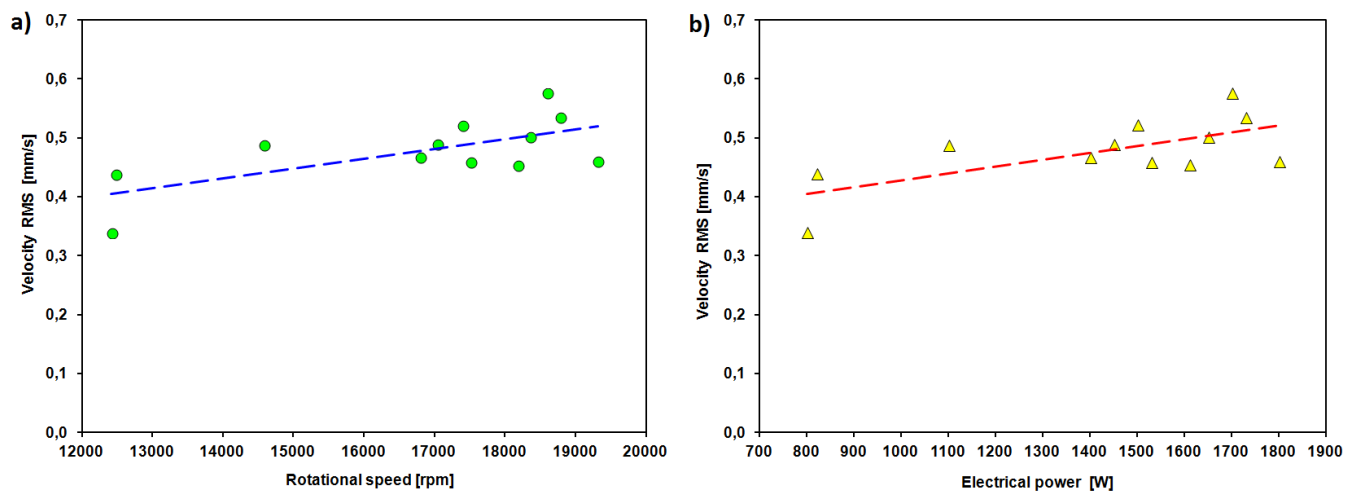

Fig. 12. RMS velocity of the radial microturbine cooperating with an ORC installation vs a) microturbine's rotational speed, b) electrical power (load)

The RMS value of vibration velocity (dashed lines) increases (from $0.41 \mathrm{~mm} / \mathrm{s}$ to $0.52 \mathrm{~mm} / \mathrm{s}$ ) with the increase of microturbine's rotational speed (from $12400 \mathrm{rpm}$ to $19300 \mathrm{rpm}$ ) and electrical power (from $800 \mathrm{~W}$ to $1800 \mathrm{~W}$ ). The maximum measured RMS value of vibration velocity was $0.576 \mathrm{~mm} / \mathrm{s}$ at rotational speed of $18600 \mathrm{rpm}$ (i.e. at a power of approx. $1700 \mathrm{~W}$ ). The minimum RMS value of vibration velocity amounted to $0.339 \mathrm{~mm} / \mathrm{s}$ and occurred at rotational speed of $12400 \mathrm{rpm}$ (i.e. about $800 \mathrm{~W}$ ).

Selected vibration spectra, measured on the microturbine casing are shown in Fig. 13 and Fig. 14.

The spectra obtained at different rotational speeds were dominated by a single synchronous vibration component - the component with a frequency corresponding to rotational speed of the rotor. The RMS value of vibration velocity did not exceed $0.576 \mathrm{~mm} / \mathrm{s}$ throughout a wide range of rotational speeds tested. This demonstrates that the microturbine operation was stable and the bearing system was functioning properly. It should be noted that the radial microturbine was mounted on a frame which was not fastened to the foundation. On the basis of the ISO 10816 standard, this microturbine may be classified as a class I machine (machines with nominal power below $15 \mathrm{~kW}$ ). The maximum RMS value of vibration velocity (i.e. $0.576 \mathrm{~mm} / \mathrm{s}$ ) of the turbine allows it to be classified in Zone A (in which the RMS vibration velocity values should fall in the range from $0.28 \mathrm{~mm} / \mathrm{s}$ to $0.71 \mathrm{~mm} / \mathrm{s}$ ), which demonstrates a very good dynamical state of the expansion device. 


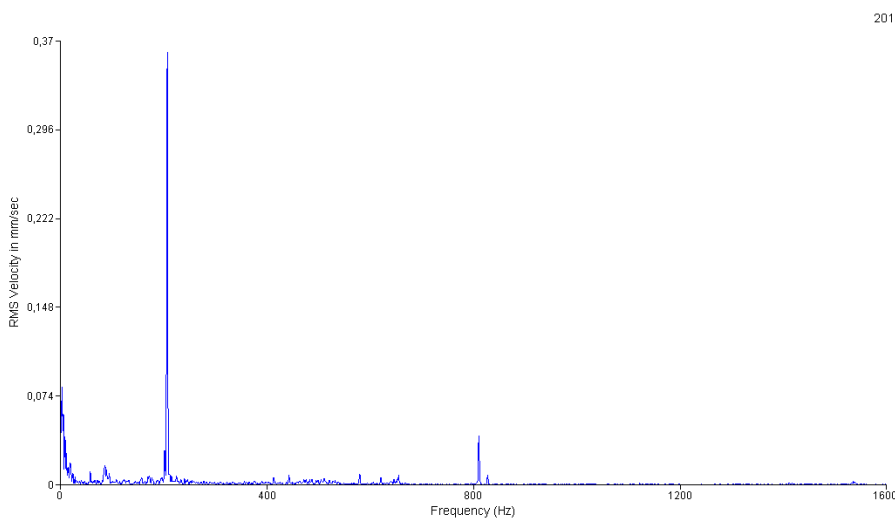

Fig. 13. Velocity spectrum of the vibrating casing of the radial microturbine at $207 \mathrm{~Hz}$
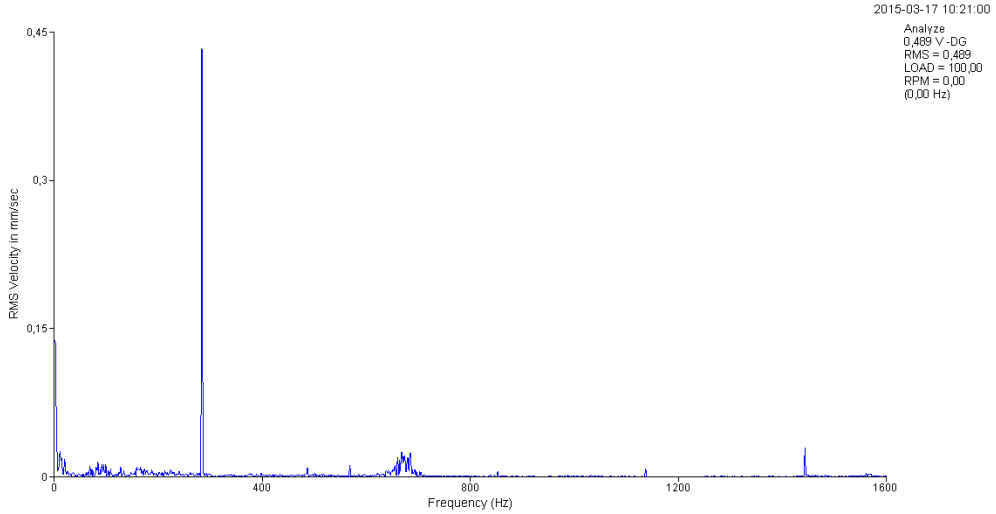

Fig. 14. Velocity spectrum of the vibrating casing of the radial microturbine at $284 \mathrm{~Hz}$

The exemplary vibration spectra presented in the range up to $1600 \mathrm{~Hz}$, obtained during measurements on a scroll expander casing, are shown in Fig. 15.

The effect of the rotational speed and the electrical power (load) of the scroll expander on the RMS vibration velocity is shown in Fig. 16(a) and Fig. 16(b).

The lowest value of RMS vibration velocity of the scroll expander $(3.61 \mathrm{~mm} / \mathrm{s})$ occurred at rotational speed of $2100 \mathrm{rpm}$ (i.e. around $650 \mathrm{~W})$ and the highest value $(6.45 \mathrm{~mm} / \mathrm{s})$ was observed at rotational speed of $2280 \mathrm{rpm}$ (i.e. electrical power of $950 \mathrm{~W}$ ). In the case of AC generator, the maximum value of RMS vibration velocity was $7.35 \mathrm{~mm} / \mathrm{s}$ at rotational speed of $2028 \mathrm{rpm}$ (i.e. about $550 \mathrm{~W}$ ). The minimum value of RMS vibration velocity measured was $4.61 \mathrm{~mm} / \mathrm{s}$ and appeared at generator's rotational speed of $2226 \mathrm{rpm}$ (i.e. electrical power of around $850 \mathrm{~W}$ ). As already mentioned, the scroll expander was connected to a low-speed AC generator using an electromagnetic clutch, which transferred the vibration onto the body of the generator. The increase of vibration level on the generator, in comparison to those of the expander, may have resulted from a larger rotor mass and a greater residual unbalance.

The tested scroll expanders are characterized by knocking and unstable operation, which manifests itself in the form of many components visible in the vibration spectra. On the basis of analyzed vibration spectra relating to the expander, it can be said that the distribution of vibration components was quite static with a slight tendency towards the increases of high frequency components at lower electrical power (i.e. when smaller power consumers were in use). On the basis of ISO 10816 standard, the scroll expander may be classified as a class I machine (i.e. machines with power below $15 \mathrm{~kW}$ ). The RMS vibration velocity level of the scroll expander remained within the range from $3.61 \mathrm{~mm} / \mathrm{s}$ to $6.45 \mathrm{~mm} / \mathrm{s}$, allowing it to be classified in Zone $\mathrm{C}$ or 
Zone D, depending on rotational speed. Machines classified in Zone C are normally considered unsatisfactory for long-term continuous operation and they may be operated only for a limited period in this condition which entails immediate planning of remedial action (e.g. maintenance or repair of a machine). Machines falling in Zone D should be taken out of service. It is noteworthy that the tested expander is the new one, recently put into service and still in its initial "run-in" stage, which certainly affected the vibration level. Moreover, it is a volumetric machine comprising eccentric elements that operate in cycles, what in turn leads to elevated vibration velocity levels. The expander was mounted on a frame which was not anchored to the foundation. Similarly as Kromulski [31] and Kumaraswamy [32] for reasons set out above, have also been struggling with selection of appropriate standards needed for expander classification. It can be concluded that there is currently a lack of standards which would allow for the assessment of technical state of volumetric machines operating in cycles that are not fastened to the foundation and their nominal power is in the range $1-3 \mathrm{~kW}_{\mathrm{e}}$.
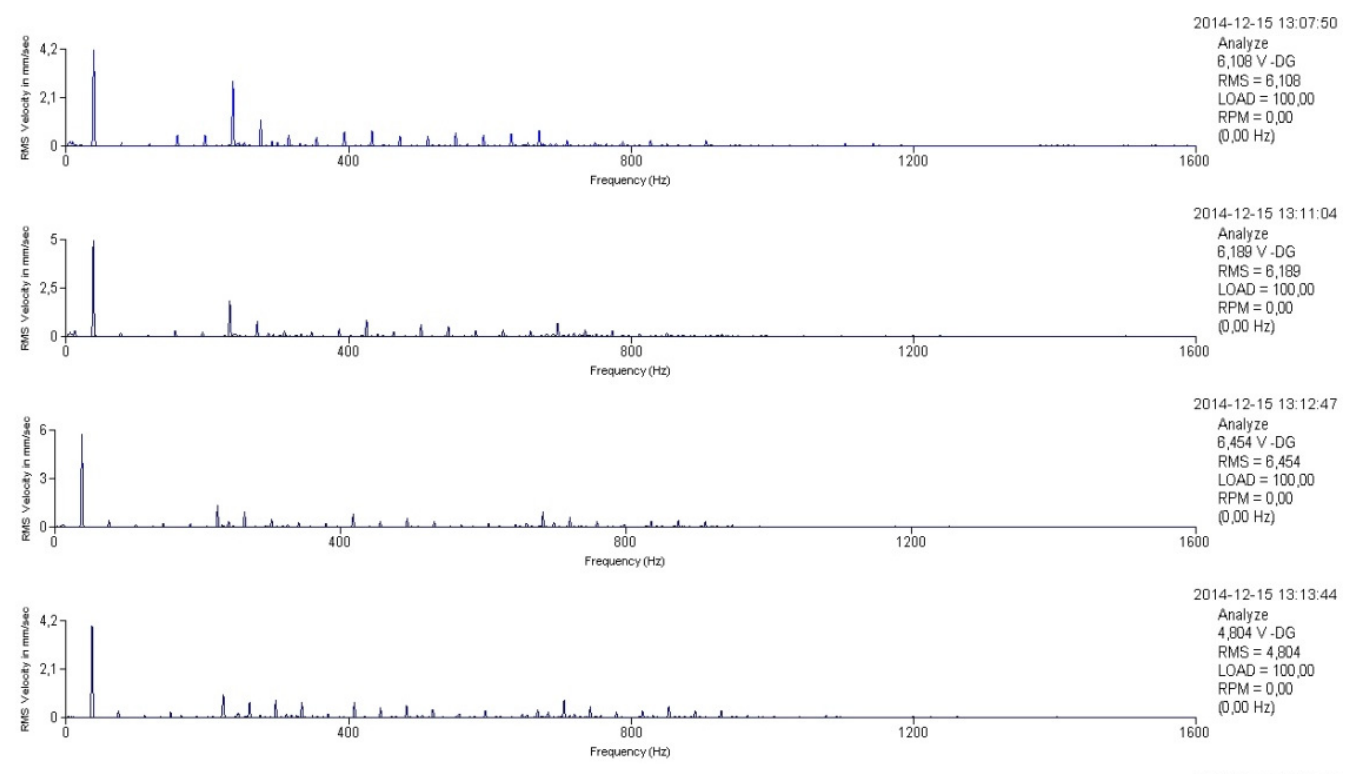

2014-12-15 13:13:44 Analyze
4,804 V -DG 4,804 V.DG RMS $=4,804$ $\angle O A D=100,00$ RPM $=0,00$
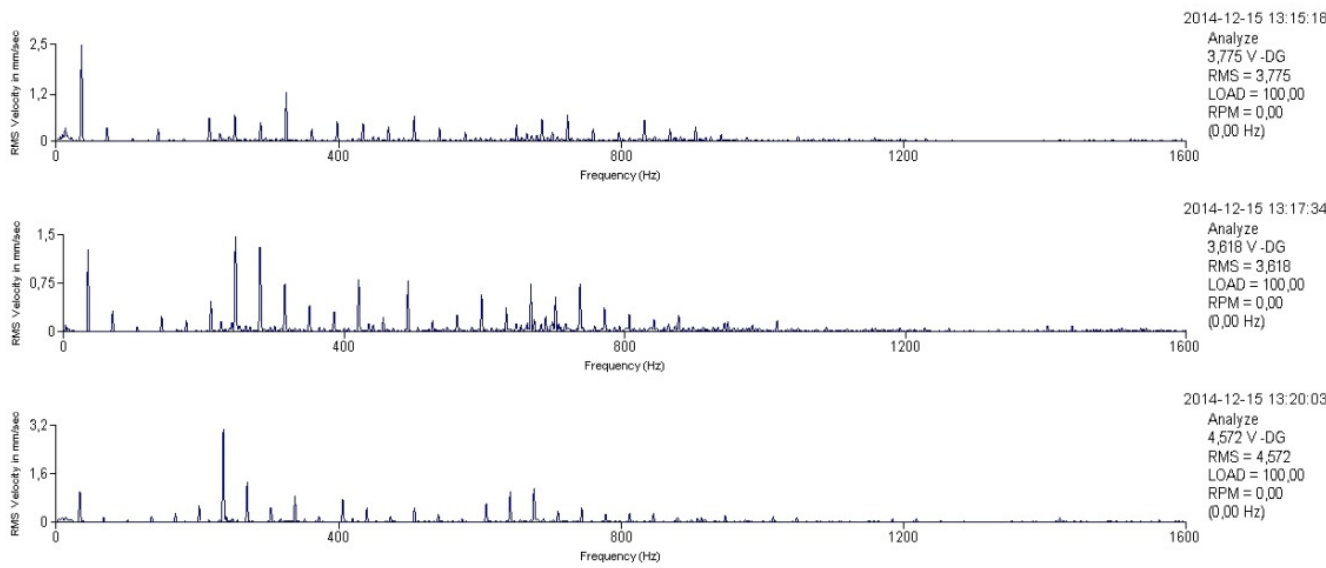

Fig. 15. RMS velocity measured on the scroll expander's housing depending on the number of currently connected electricity consumers 

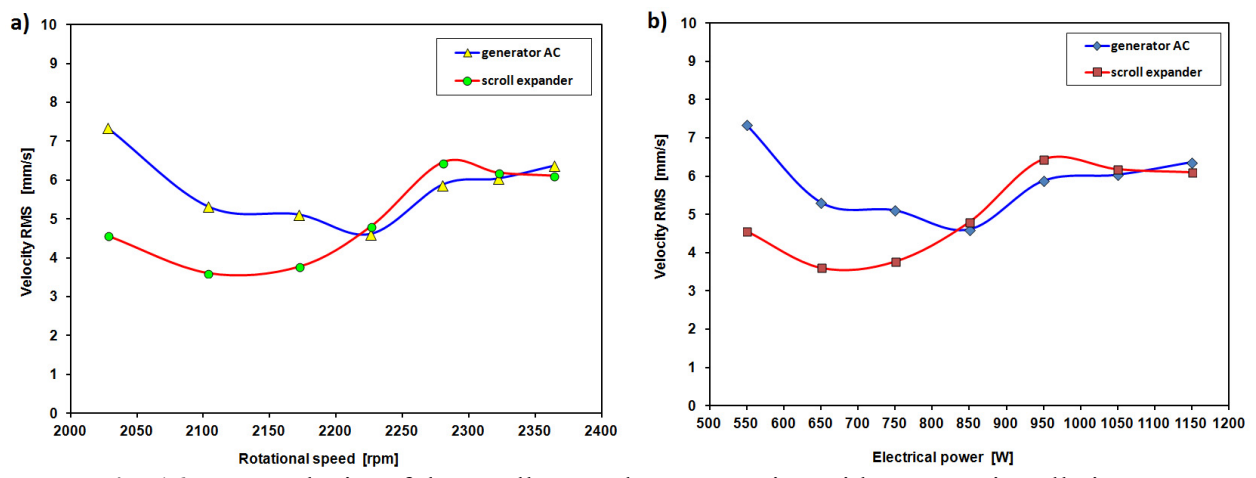

Fig. 16. RMS velocity of the scroll expander cooperating with an ORC installation vs a) expander's rotational speed, b) electrical power (generator load)

\section{Conclusions}

The paper presents the results of experimental research carried out for a four-stage radial microturbine and a scroll expander which were incorporated into the ORC system, focusing on the analysis of vibration and noise levels. Results of a research on noise and vibration emitted by expansion machinery used in cogeneration systems with power capacities ranging from $1 \mathrm{~kW}_{\mathrm{e}}$ to $3 \mathrm{~kW}_{\mathrm{e}}$ were not presented by any other researcher and can be employed by designers and engineers for the construction of domestic cogeneration systems based on the ORC technology. This is particularly important in the present context of growing interest for small cogeneration systems, which are increasingly being used in residential buildings.

The overall conclusion is that vapour microturbines are expansion devices that exhibit significantly better usable characteristics as compared with those of scroll expanders. (both in terms of vibration level and acoustical noise emissions). This is of particular relevance for low-power cogeneration units, intended for domestic uses. Apart from high performance and reliability, such devices need to provide a high level of user comfort and a sense of security.

\section{References}

[1] Directive 2009/28/EC of the European Parliament and of the Council of 23 April 2009 on the Promotion of the Use of Energy from Renewable Sources and Amending and Subsequently Repealing Directives 2001/77/EC and 2003/30/EC, (in Polish).

[2] Law on Renewable Sources of Energy Adopted on 20 February 2015. Journal of Laws, Item 478, 2015, (in Polish).

[3] Woźny A., Dobosz D., Pacana A. Influence of noise on the quality of work. Humanities and Social Sciences, Vol. 19, Issues 21-2, 2014, p. 251-258, (in Polish).

[4] Leśniewska-Matusiak I., Wnuk A. Influence of communication noise upon the components of the acoustic environment that can be perceived by humans. Transport Samochodowy (Road Transport), Vol. 3, 2014, p. 37-63, (in Polish).

[5] Sadowski J. Noise assessment at the workplace and minimising its impact on the human body. Inżynieria i Aparatura Chemiczna (Chemical Engineering and Equipment), Vol. 52, Issue 2, 2013, p. 110-112, (in Polish).

[6] Marczak P. Chief specialist at the information and documentation office of the senate chancellery. danger posed by noise. Selected Issues, Thematic Paper OT-612, 2012, (in Polish).

[7] Training Materials. Noise in the Work Environment. Hazards and Prevention. Internet Service of the Central Institute for Labour Protection - National Research Institute, p. 1-21, (in Polish).

[8] National Focal Point. Noise - the Most Important Information, European Week for Safety and Health at Work 2005, Central Institute for Labour Protection - National Research Institute, p. 1-12, (in Polish). 
[9] Kiprian K., Ligus G. Some problems of assessment and forecasting of acoustic emission from industrial significant sources. Prace Instytutu Ceramiki i Materiałów Budowlanych, Vol. 4, Issue 7, 2011, p. 118-131, (in Polish).

[10] Mirowska M. Noise in buildings - updating of Polish standards. Bezpieczeństwo Pracy (Safety at Work), Vols. 7-8, 2007, p. 16-19, (in Polish).

[11] Mikulski W., Kaczmarska A., Koton J. Noise at Workplaces. p. 1-27, (in Polish).

[12] Urba R., Kwilosz T. Noise emission by drilling equipment into drill rig service environment. NAFTA-GAZ, Vol. 12, 2012, p. 1055-1062, (in Polish).

[13] Labęda M. Information on Noise in the Work Environment, Legal Status as at 31 December 2013. Trading and Service Company, Work Environment Research Centre "TOX-LUX", 2013, (in Polish).

[14] Lutyński A. Identification of noise pressure level in the work environment at the plants for processing of bituminous coal. Górnictwo i Geoinżynieria (Mining and Geoengineering), Vol. 3, Issue 1, 2006, p. 173-180, (in Polish).

[15] Concerning determining penalties for breach of the conditions of disposal of sewage to water or soil and for exceedance of admissible levels of noise emission to the environment. Decree of the Minister of Environment (Official Journal of the Republic of Poland "Monitor Polski"), Item 904, 2015, (in Polish).

[16] Amending the decree on essential requirements relating to the noise emission in the environment by equipment for use outdoors. Decree of the Ministry of Economy (Journal of Laws), Vol. 105, Item 718, 2007, (in Polish).

[17] Decree of the Ministry of Economy dated 21 December 2005 on essential requirements relating to the noise emission in the environment by equipment for use outdoors (Journal of Laws, No. 263, item 2202) (in Polish).

[18] Zalewski M. Noise - one of the main performance parameters of compressor appliances. Requirements and examples of protection methods. Chłodnictwo and Klimatyzacja, Vol. 9, 2008, p. 2-3, (in Polish).

[19] Directive 98/37/EC of the European Parliament and of the Council of 22 June 1998 on the Approximation of the Laws of the Member States Relating to Machinery, (in Polish).

[20] Directive 2006/42/EC of the European Parliament and of the Council of 17 May 2006 on Machinery, and Amending Directive 95/16/EC (recast), (in Polish).

[21] Essential requirements for machines relating the safety issues. Decree of the Ministry of Economy (Journal of Laws), 2005, (in Polish).

[22] Notices from European Union Institutions, Bodies, Offices and Agencies, European Commission, Commission communication in the framework of the implementation of the Directive 2006/42/EC of the European Parlamient and of the Council of 17 May 2006 on machinery, and emending Directive 95/16/EC (recast). Official Journal of the European Union C 87/1, 2012, (in Polish).

[23] Essential requirements for machinery. Decree of the Ministry of Economy (Journal of Laws), Vol. 199, Item 1228, 2008, (in Polish).

[24] Wieczorek A. N. Designing machinery and equipment in accordance with the principle of sustainable development. Management Systems in Production Engineering, Vol. 1, Issue 17, 2015, p. 1-12.

[25] Makarewicz G. Noise in the work environment. Promotor Vol. 5, Issue 12, p. 18-26, (in Polish).

[26] Jaskólski J., Budzik G. The problems about infrasonic noise and their influence on human health in engine test bench. 26th International Scientific Conference on Combustion Engines, Nałęczów, 2000, p. 166-169, (in Polish).

[27] Klimanowski M. Vibroacoustic diagnostics in compliance with PN (Polish Standard) and ISO applicable regulations. Zeszyty Problemowe - Maszyny Elektryczne, Vol. 2, Issue 99, 2013, p. 115-120, (in Polish).

[28] Kokociński J. Vibroacoustic diagnostics of machinery. Energetyka Cieplna i Zawodowa, Vol. 11, 2009, p. 44-50, (in Polish).

[29] Robichaud J. M. Reference Standards for Vibration Monitoring and Analysis. Bretech Engineering Ltd., Saint John, NB Canada, 2004.

[30] Tomaszewski J., Rysinski J. Diagnostics of gears and compressors by means of advanced automatic system. Acta Mechanica et Automatica, Vol. 9, Issue 1, 2015, p. 19-22.

[31] Kumaraswamy S., Rakesh J., Nalavade A. K. Standardization of absolute vibration level and damage factors for machinery health monitoring. Proceedings of VETOMAC-2, 2002, p. 1-8.

[32] Kromulski J., Wojciechowski J., Mac J., Pawłowski T. Estimation of dynamic condition of pneumatic conveyor for seed. Technika Rolnicza Ogrodnicza Leśna, Vol. 2, 2013, p. 9-11, (in Polish). 
[33] Toczek W. Damping of a steam turbine self-excited vibrations with the use of four-key bearings. Energetyka, 2013, p. 351-353.

[34] Kowalski K. Repairs of the flow systems in steam turbines directed towards achieving the guaranteed parameters of energy conversion effectiveness. The Second Conference of Electricity Producers, Skawina, 2011, p. 109-121, (in Polish).

[35] Wachel J. C. Turbine and compressor vibrations. Ammonia Plant Safety, American Institute of Mechanical Engineers, Vol. 15, 1973, p. 69-76.

[36] Szymaniec S. Natural vibrations of squirrel-cage induction motor stator of low power - measurements. Zeszyty Problemowe - Maszyny Elektryczne, Vol. 96, Issue 3, 2012, p. 25-30, (in Polish).

[37] Szymaniec S. Measurements of natural frequency and resonant frequency of electric machines in operating conditions. Zeszyty Problemowe - Maszyny Elektryczne, Vol. 96, Issue 3, 2012, p. 31-36, (in Polish).

[38] Żywica G., Bagiński P., Breńkacz Ł. Dynamic state assessment of the water turbine with the power of $600 \mathrm{~kW}$. Diagnostyka, Vol. 14, Issue 1, 2013, p. 65-70.

[39] Jarzyna T. Dynamic analysis of a vertical two-stage mixed flow pump. Inżynieria i Aparatura Chemiczna (Chemical Engineering and Equipment), Vol. 51, Issue 1, 2012, p. 13-15, (in Polish).

[40] Liu T., Wu Z. A vibration analysis based on wavelet entropy method of a scroll compressor. Entropy, Vol. 17, 2015, p. 7076-7086.

[41] Rockwood W. B. Noise and vibration characterization and statistical energy analysis of a scroll compressor. International Compressor Engineering Conference, School of Mechanical Engineering, 1998, p. 331-336.

[42] Wodzicki W. Vibration of machines with deformable bodies elasticity supported on flexible structures. Journal of Theoretical and Applied Mechanics, Vol. 13, Issue 2, 1975, p. 169-181, (in Polish).

[43] Zargar O. A. Turbine compressor vibration analysis and rotor movement evaluation by shaft center line method (The case history related to main turbine compressor of an Olefin plant in Iran oil industries). World Academy of Science, Engineering and Technology International Journal of Mechanical, Aerospace, Industrial, Mechatronic and Manufacturing Engineering Vol. 8, Issue 1, 2014.

[44] Grządziela A. Modern methods used to measure vibrations in identification of technological errors in rotating machines. Scientific Papers of Polish Naval Academy, Vol. 177, Issue 2, 2009, p. 7-18, (in Polish).

[45] Kiciński J., Żywica G., Bagiński P. The dynamic performance analysis of the micro-turbine's rotor supported on slide and rolling element bearings. The 10th International Conference on Vibration Problems, Prague, Czech Republic, 2011.

[46] Kiciński J., Żywica G., Miąskowski W. The dynamic properties of the micro-rotor supported on fluid-film bearings. Proceedings of the 8th IFToMM International Conference on Rotordynamics, KIST, Seoul, South Korea, 2010, p. 1-5.

[47] Żywica G., Drewczyński M., Kiciński J., Rządkowski R. Computational modal and strength analysis of the steam microturbine with fluid-film bearings. Journal of Vibration Engineering and Technologies, Vol. 2, Issue 6, 2014, p. 543-549.

[48] Żywica G., Kiciński J. The influence of selected design and operating parameters on the dynamics of the steam micro-turbine. Open Engineering, Vol. 5, Issue 1, 2015, p. 385-398.

[49] Health and safety at work relating to the exposure to noise and mechanical vibration. Decree of the Minister of Economy and Labour of the Republic of Poland (Journal of Laws), Vol. 157, Item 1318, 2005.

[50] Maximum permissible concentration and intensity of harmful factors in the work environment. Decree of the Minister of Labour and Social Policy (Journal of Laws), Vol. 217, Item 1833, 2002.

[51] Kaczmarczyk T. Z., Żywica G., Ihnatowicz E. The experimental investigation of the biomass-fired ORC system with a radial microturbine. Applied Mechanics and Materials, Vol. 831, 2016, p. 235-244.

[52] Kaczmarczyk T. Z., Ihnatowicz E. The experimental investigation of scroll expanders operating in the ORC system with HFE7100 as a working medium. Applied Mechanics and Materials, Vol. 831, 2016, p. 245-255.

[53] Kaczmarczyk T. Z., Żywica G., Ihnatowicz E. The Use of Expansion Devices in ORC Cogeneration Systems. IFFM Publisher, Gdańsk, 2015, (in Polish).

[54] http://airsquared.com/products/expanders/E15H22N4.25

[55] Vibration Analyzer Catalogue Card (SCI 2140 manufactured by Emerson).

[56] Sound Analyzer Catalogue Card (Nor140 manufactured by Norsonic). 
[57] Kuminek T., Aniołek K., Młyńczak J. A numerical analysis of the contact stress distribution and physical modelling of abrasive wear in the tram wheel-frog system. Wear, Vol. 328, 2015, p. 177-185.

[58] Młyńczak J. Computer Analysis of the Setting Force. Activities of Transport Telematics. Book Series: Communications in Computer and Information Science, Vol. 395, Springer, Heidelberg, 2013, p. 131-138.

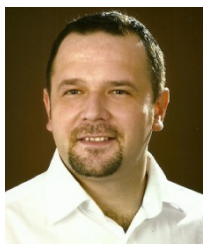

Tomasz Z. Kaczmarczyk, Ph.D., Eng. received his M.Sc. Eng. degree in Mechanical Engineering from Gdańsk University of Technology in 2005 and M.Sc. Eng. degree in Electrical and Control Engineering from Gdańsk University of Technology in 2008, as well as his Ph.D. degree in 2012. Since 2013 he has been a research associate at the Institute of Fluid-Flow Machinery of the PAS. From 2014 working in the Department of Turbine Dynamics and Diagnostics. Main area of research: heat transfer and heat exchangers, nanofluids, design and construction of steel structures, RES and ORC systems.

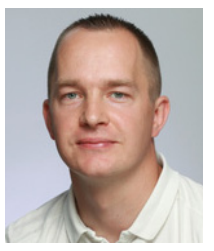

Grzegorz Żywica, Ph.D., Eng. Since 2005 has been working at the Institute of Fluid-Flow Machinery PAS in Gdansk. Head of the Department of Turbine Dynamics and Diagnostics. In the scientific work he deals with the problems of computational simulation and design of the turbomachinery, bearing systems, modal analysis and technical diagnostics.

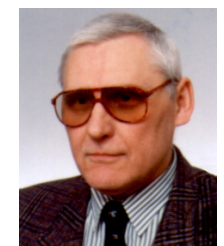

Eugeniusz Ihnatowicz, Ph.D., Eng. Since 1969 has been working at the Institute of Fluid Flow Machinery PAS in Gdańsk, at the Thermodynamics and Heat Transfer Department. Starting from 2014 is in cooperation with the Turbine Dynamics and Diagnostics Department. Main area of research: thermodynamics and heat transfer, heat transfer with phase changes, two-phase flows, film flows, swirl flows and jets, power engineering equipment, ORC cycle, micro CHP, renewable heat source. 